\title{
Coleopterofauna found on fresh and frozen rabbit carcasses in Curitiba, Paraná, Brazil
}

\author{
Mise*, KM., Corrêa, RC. and Almeida, LM. \\ Laboratório de Sistemática e Bioecologia de Coleoptera, Departamento de Zoologia, Universidade Federal do Paraná, \\ CP 19020, CEP 81531-980, Curitiba, PR, Brazil \\ *e-mail: klebermise@yahoo.com.br
}

Received June 13, 2012 - Accepted September 12, 2012 - Distributed August 31, 2013

\begin{abstract}
Many arthropod species are associated with carrion and some of them can be used as forensic indicators in murder investigations to estimate the time of death. Different physical conditions of cadavers may influence the fauna and the importance of freezing and thawing is unknown. The present paper sought to survey the Coleoptera species encountered in frozen and fresh rabbit carcasses, at a forest in Curitiba, Brazil. Four rabbit carcasses, two of them fresh and the other frozen were used. The coleopterofauna was sampled daily, and analyzed using non-parametric tests. A total of 666 beetles were sampled, belonging to 28 species in 10 families. Most of the beetles captured were larvae of Oxelytrum spp. (433) which are known to be necrophagous. The two frozen carcasses accounted for most of the beetles (338 and 180) in comparison with the two fresh carcasses (103 and 45). The tests were based on the most abundant species. Oxelytrum spp. median differed significantly between carcasses $(H=12.47844 ; \mathrm{p}=0.0059)$. The two fresh carcasses differed significantly $(\mathrm{U}=190.0 ; \mathrm{p}=0.00019)$, but there was no significant difference between the frozen carcasses $(U=336.0 ; p=0.29755)$. The data indicate that the freezing process prevents certain species to colonize carcasses, in this case with the dominance of species of Oxelytrum. These data also indicate that careful attention is necessary before using frozen carcasses in forensic entomology studies.
\end{abstract}

Keywords: beetles, carrion fauna, forensic entomology, Oxelytrum spp. and cause of death.

\section{Coleopterofauna encontrada em carcaças de coelho congeladas e frescas em Curitiba, Paraná, Brasil}

\section{Resumo}

Muitas espécies de artrópodes são associadas a carcaças e algumas delas podem ser utilizadas em casos de morte violenta como indicadoras forenses do intervalo decorrido desde a morte do indivíduo. Diferentes condições físicas dos cadáveres podem influenciar a fauna, sendo que o efeito do congelamento e descongelamento é desconhecido. Os objetivos do presente trabalho foram levantar as espécies de Coleoptera em carcaças de coelho frescas e congeladas em um remanescente florestal localizado em Curitiba, Brasil. Foram utilizadas quatro carcaças de coelhos, dois frescos e dois previamente congelados. A coleopterofauna foi amostrada diariamente e analisada com testes não paramétricos. Foram coletados 666 espécimes, pertencentes a 28 espécies, de 10 famílias. A maioria dos besouros coletados foi representada por larvas de Oxelytrum spp. (433), as quais são necrófagas. Observou-se um maior número de indivíduos sobre as carcaças congeladas (338 e 180) em comparação com as duas frescas (103 e 45). Os testes foram baseados nas espécies mais abundantes. A mediana das espécies de Oxelytrum diferiu significativamente entre as carcaças $(H=12,47844 ; p=0,0059)$. As duas carcaças frescas diferiram significativamente $(U=190,0 ; p=0,00019)$, porém não houve diferença significativa entre as carcaças congeladas $(U=336,0 ; p=0,29755)$. Os dados indicaram que o processo de congelamento evitou que algumas espécies colonizassem as carcaças, neste caso com dominância de espécies de Oxelytrum. Estes dados também indicam a necessidade de cuidado ao utilizar carcaças congeladas em estudos de entomologia forense.

Palavras-chave: besouros, fauna necrófaga, entomologia forense, Oxelytrum spp. e carcaça de coelho.

\section{Introduction}

Carrion represents a micro-habitat providing a temporary, changing food source for a distinct community of organisms (Tullis and Goff, 1987). The main organisms associated with this process are bacteria, fungi and various groups of arthropods (Putman, 1978). The cadaveric fauna could then be used to establish time of death (postmortem interval) and to know if a human body has been 
moved or partly concealed during decomposition (Smith, 1986). Among this fauna, Coleoptera is one of the most important orders, and it is considered the main entomological evidence when skeletal human remains are found (Kulshrestha and Satpathy, 2001) and when the remains are recovered outdoors (Goff, 1991).

However the entomological data may depend on the previous and posterior conditions of death, as these factors affect the succession (Byrd and Castner, 2001), which is used in the PMI estimation. This happens because the environmental variables may slow down or speed up insects arrival. Among these factors, season, environmental temperature and air humidity affect insects development (Marchenko, 2001) and species presence (Archer and Elgar, 2003). Body access is another important factor (Mann et al., 1990). Conditions in which the body is buried (Corrêa and Almeida unpublished data), enclosed in cars (Voss et al., 2008), or wrapped in blankets (Goff, 1992) may alter the entomological succession.

Some studies addressed that different physical conditions of corpses may influence the fauna. It is known that the fauna changes in buried, burnt or hanged carcasses (Motter, 1898; Avila and Goff, 1998; Vanlaerhoven and Anderson, 1999; Shalaby et al., 2000). In burnt corpses, fly oviposition may occur faster and the decomposition process can be hastened by four days (Avila and Goff, 1998). Few studies addressed the importance of freezing and thawing over the body (Micozzi, 1986; Stokes et al., 2009) and no studies were found about their effects over the fauna. Such studies are necessary as small changes may alter the whole entomological succession in a highly competitive environment and many studies use defrosted carcasses in succession entomological studies (Payne, 1965; Tullis and Goff, 1987).

It is known that freezing/thawing allows the formation of ice crystals that lead to body dehydration (Stokes et al., 2009), which alter the growth pattern of enteric fauna. Another effect is that the external parts of the body would be the first to thaw being then directly exposed to microorganisms from outside (Zugibe, 1993). Therefore, the body decomposition process occurs "outside-in", while normally it happens "inside-out” (Micozzi, 1986). If the freezing is caused by low environmental temperatures, it is known that at $5-13{ }^{\circ} \mathrm{C}$ flies will continue visiting the carcasses, but at $0{ }^{\circ} \mathrm{C}$ their eggs will die. However, fly larvae may survive if they stay inside the body (Mann et al., 1990). The low temperatures effect to carrion beetles is unknown.

Gunn (2006) mentioned that murderers sometimes store their victim's body in a freezer before disposing of it, which was also reported by Zugibe and Costello (1993) in the USA, where a human body was stored in a freezer prior to disposal. The freezing/thawing process can also be due to a cold environment or to a deliberate preservation prior to burial or experimental procedures (Stokes et al., 2009). In this way, it is necessary to study their effects over the entomofauna to analyse the results when such process is confirmed. Day and Wallman
(2006) tested if the freezing/thawing affects the growth of Calliphora augur (Fabricius), and concluded that there was no significant effect. However the effects of this process over the entomological succession, remains unknown.

The present paper sought to survey the Coleoptera encountered in frozen and fresh rabbit carcasses.

\section{Materials and Methods}

The experiment took place from December 2007 to January 2008 in the "Mata Viva" Reserve $\left(25^{\circ} 26^{\prime} 45^{\prime}\right.$ " S $49^{\circ} 13^{\prime} 58^{\prime \prime} \mathrm{W}$; $900 \mathrm{~m}$ over sea level), located at Universidade Federal do Paraná (Curitiba, Paraná, Brazil). The average annual temperature varies between $17-18^{\circ} \mathrm{C}$ and annual relative humidity between $80-85 \%$ (IAPAR 2011). The vegetation is Mixed Rain Forest in different successional stages (Reginato et al., 2008).

Four rabbit (Oryctolagus cuniculus L., 1758) carcasses weighting approximately $1 \mathrm{~kg}$ were used as bait to sample the Coleoptera. The rabbits were killed by cervical dislocation, being two of them frozen two days prior to the beginning of the experiment and the other two being killed at the local. The carcasses were placed inside metallic cages, 8 meters away from each other, under direct sunlight. Active samplings were conducted daily to capture both immature and adult specimens, which were stored in plastic jars and killed, mounted and identified in laboratory. The samplings were made for 30 days, time period in necessary for the carcass to reach the dry remains stage. The identification was done using keys (Mazur, 2002; Navarrete-Heredia et al., 2002; Almeida and Mise, 2009) and specialists help.

Diversity indexes were calculated in Past 1.91 (Hammer et al., 2001) and statistical tests were conducted using Statistica 7.0 (Statsoft, 2004). The tests were based on the most abundant species, to verify the possible good forensic indicators. First a Kolmorogov-Smirnov test was done to verify if the data fit a normal distribution, as it did not, $\log (x+1)$ and $\sqrt{x+0.5}$ transformations were tried, which again did not fit a normal distribution. As the premises of ANOVA were not met, a non-parametric test (Kruskal-Wallis) was used instead to compare all carcasses. To compare frozen $\mathrm{x}$ frozen and fresh $\mathrm{x}$ fresh, a Wilcoxon-Mann-Whitney test was used to see if they differed significantly. To compare the diversity found on the carcasses Shannon and Berger-Parker diversity indexes were used.

\section{Results and Discussion}

A total of 666 beetles were sampled, belonging to 20 species in 10 families. Silphidae had the greater number of specimens, followed by Staphylinidae, Leiodidae and Histeridae. The low number of Staphylinidae was not expected, as species of this family were abundant in $15 \mathrm{~kg}$ pig carcasses (Mise et al., 2007, 2008), probably because of the difference in carcass size. Most of the beetles captured were larvae of Oxelytrum spp. (433) which are known to be necrophagous. Such high number was ex- 
pected as $O$. discicolle (Brullé 1840) was previously encountered in laboratory-bred Rattus norvegicus (Berkenhout, 1769) carcasses (Moura et al., 1997) and Sus scrofa L., 1758 carcasses (Mise et al., 2007), in the same study area. It was also recorded in rabbit carcasses at Rio Grande do Sul state, south of Brazil (Souza et al., 2008) and in human corpses in Cali, Colombia (Barreto et al., 2002) and São Paulo state, Brazil (Carvalho et al., 2000).

The succession is illustrated (Tables 1-4), indicating that when analyzed in a week-basis, most species arrival and departure times occur only one time, with few recolonizations. These data are different from the ones ob- tained by Mise et al. (2007), probably because small carcasses enable only one generation before disappearing.

The frozen carcasses accounted for most of the beetles (338 for frozen 1, and 180 for frozen 2) in comparison with the fresh (103 for fresh 1, and 45 for fresh 2). Regarding the richness, the lowest value was measured in the last frozen carcass, mainly due to the great number of ants found. The richness varied, with 12 and 10 species in the fresh carcasses and 11 and 7 species in the frozen carcasses (Table 5). Comparing the fauna found on the carcasses, the higher Shannon diversity index was found on the fresh ones, which indicates that the freezing process

Table 1 - Species of Coleoptera collected during a four-week study in fresh rabbit carcass (fresh 1) in Curitiba, PR, Brazil.

\begin{tabular}{|c|c|c|c|c|c|}
\hline \multicolumn{2}{|l|}{ Taxon } & \multicolumn{4}{|c|}{ Week } \\
\hline Family & Species & 1 & 2 & 3 & 4 \\
\hline Chrysomelidae & Chrysomelinae sp. & 0 & 0 & 0 & 1 \\
\hline Cleridae & Necrobia rufipes (Degeer, 1775) & 0 & 2 & 0 & 1 \\
\hline Histeridae & Euspilotus nigrita (Blanchard, 1842) & 2 & 0 & 0 & 0 \\
\hline Histeridae & Phelister sp. & 0 & 0 & 1 & 2 \\
\hline Histeridae & Aeletes sp. & 0 & 0 & 0 & 1 \\
\hline Leiodidae & Dissochaetus murrayi (Reitter, 1884) & 0 & 1 & 3 & 17 \\
\hline Ptiliidae & Ptiliidae sp. & 0 & 0 & 0 & 1 \\
\hline Silphidae & Oxelytrum spp. & 6 & 1 & 5 & 0 \\
\hline Silphidae & Larvae of Oxelytrum spp. & 3 & 26 & 9 & 10 \\
\hline Staphylinidae & Aleochara pseudochrysorrhoa Caron, Mise \& Klimaszewski, 2008 & 1 & 6 & 1 & 0 \\
\hline Staphylinidae & Anotylus sp. & 0 & 1 & 0 & 0 \\
\hline Staphylinidae & Larvae of Staphylinidae sp. 2 & 0 & 0 & 0 & 1 \\
\hline Staphylinidae & Larvae of Staphylinidae sp. 3 & 0 & 0 & 0 & 1 \\
\hline
\end{tabular}

Table 2 - Species of Coleoptera collected during a four-week study in frozen rabbit carcass (frozen 1) in Curitiba, PR, Brazil.

\begin{tabular}{|c|c|c|c|c|c|}
\hline \multicolumn{2}{|l|}{ Taxon } & \multicolumn{4}{|c|}{ Week } \\
\hline Family & Species & 1 & 2 & 3 & 4 \\
\hline Dermestidae & Dermestes maculatus (DeGeer, 1774) & 1 & 0 & 0 & 0 \\
\hline Histeridae & Euspilotus nigrita & 4 & 7 & 0 & 0 \\
\hline Histeridae & Phelister sp. & 0 & 2 & 1 & 3 \\
\hline Hydrophilidae & Dactylosternum sp. & 0 & 0 & 2 & 0 \\
\hline Leiodidae & Dissochaetus murrayi & 0 & 0 & 6 & 16 \\
\hline Silphidae & Oxelytrum spp. & 13 & 1 & 0 & 0 \\
\hline Silphidae & Larvae of Oxelytrum spp. & 3 & 231 & 22 & 0 \\
\hline Staphylinidae & Aleochara pseudochrysorrhoa & 5 & 12 & 0 & 0 \\
\hline Staphylinidae & Phylonthus sp. & 1 & 1 & 0 & 0 \\
\hline Staphylinidae & Atheta iheringi Bernhauer, 1908 & 1 & 0 & 0 & 0 \\
\hline Staphylinidae & Larvae of Staphylinidae sp. 1 & 0 & 0 & 1 & 0 \\
\hline Staphylinidae & Larvae of Staphylinidae sp. 2 & 0 & 0 & 0 & 5 \\
\hline
\end{tabular}


reduces species eveness on carcasses. This is corroborated by the Berger-Parker index, a dominance measure, which was higher on the frozen carcasses because of the high abundance of Oxelytrum species.

As Oxelytrum spp. accounted for $65.01 \%$ of the specimens and they are known to feed and breed on carcasses (Peck and Anderson, 1985), their abundance was used to test if the genus can be an indicator when a freezing process occurs.
The median differed significantly when all carcasses were used $(\mathrm{H}=12.47844 ; \mathrm{p}=0.0059)$. A WilcoxonMann-Whitney test was conducted to test if they differed significantly between treatments (fresh $\mathrm{x}$ fresh; frozen $\mathrm{x}$ frozen). The two fresh carcasses differed significantly $(\mathrm{U}=190.0 ; \mathrm{p}=0.00019)$, but there was no significant difference between the frozen carcasses $(\mathrm{U}=336.0$; $\mathrm{p}=0.29755$ ). The data indicate that the freezing process prevents certain species to colonize carcasses, probably

Table 3 - Species of Coleoptera collected during a four-week study in fresh rabbit carcass (fresh 2) in Curitiba, PR, Brazil.

\begin{tabular}{|c|c|c|c|c|c|}
\hline \multicolumn{2}{|l|}{ Taxon } & \multicolumn{4}{|c|}{ Week } \\
\hline Family & Species & 1 & 2 & 3 & 4 \\
\hline Histeridae & Euspilotus nigrita & 1 & 4 & 0 & 0 \\
\hline Histeridae & Phelister sp. & 0 & 2 & 1 & 0 \\
\hline Hydrophilidae & Dactylosternum sp. & 0 & 0 & 1 & 0 \\
\hline Leiodidae & Dissochaetus murrayi & 0 & 0 & 2 & 8 \\
\hline Silphidae & Oxelytrum spp. & 1 & 0 & 0 & 0 \\
\hline Silphidae & Larvae of Oxelytrum spp. & 1 & 5 & 0 & 0 \\
\hline Staphylinidae & Aleochara pseudochrysorrhoa & 4 & 5 & 1 & 0 \\
\hline Staphylinidae & Phylonthus sp. & 0 & 1 & 0 & 0 \\
\hline Staphylinidae & Belonuchus sp. & 0 & 0 & 1 & 0 \\
\hline Staphylinidae & Larvae of Staphylinidae sp. 1 & 0 & 0 & 4 & 1 \\
\hline Staphylinidae & Larvae of Staphylinidae sp. 2 & 0 & 0 & 0 & 2 \\
\hline
\end{tabular}

Table 4 - Species of Coleoptera collected during a four-week study in frozen rabbit carcass (frozen 2) in Curitiba, PR, Brazil.

\begin{tabular}{|c|c|c|c|c|c|}
\hline \multicolumn{2}{|l|}{ Taxon } & \multicolumn{4}{|c|}{ Week } \\
\hline Family & Species & 1 & 2 & 3 & 4 \\
\hline Cleridae & Necrobia rufipes & 0 & 3 & 0 & 0 \\
\hline Histeridae & Euspilotus nigrita & 3 & 1 & 0 & 0 \\
\hline Histeridae & Phelister sp. & 0 & 1 & 0 & 0 \\
\hline Silphidae & Oxelytrum spp. & 30 & 3 & 0 & 0 \\
\hline Silphidae & Larva of Oxelytrum spp. & 9 & 114 & 0 & 0 \\
\hline Staphylinidae & Aleochara pseudochrysorrhoa & 3 & 11 & 0 & 0 \\
\hline Staphylinidae & Coproporus sp. & 0 & 0 & 0 & 1 \\
\hline Scarabaeidae & Ataenius spp. & 0 & 0 & 1 & 0 \\
\hline
\end{tabular}

Table 5 - Measures of diversity of fresh and frozen rabbit carcasses, calculated based on beetles sampled during four weeks in Curitiba, PR, Brazil.

\begin{tabular}{lcccc}
\hline & Richness & Abundance & Shannon index & Berger-Parker index \\
\hline Fresh 1 & 12 & 103 & 1.39 & 0.5825 \\
Frozen 1 & 11 & 338 & 0.8654 & 0.7988 \\
Fresh 2 & 10 & 45 & 2.019 & 0.2222 \\
Frozen 2 & 7 & 180 & 0.562 & 0.8667 \\
\hline
\end{tabular}


reducing competition and therefore allowing a more patterned succession, in this case with the dominance of Oxelytrum spp. Low temperatures $\left(<4{ }^{\circ} \mathrm{C}\right)$ slow down putrefaction, by interfering in the bacterial activity (Micozzi, 1987), even during the thawing process in environmental temperature (Micozzi, 1986), reducing also the smell liberated during the first hours. This could be observed in the present study, as the initial decomposition process took longer in the frozen carcasses, but as the study did not aim to compare their decomposition, only their fauna, this could not be measured. Such factors may have benefited beetles, mainly Oxelytrum spp., over other competitors, including flies. These data indicate that a careful approach is necessary before using frozen carcasses in forensic entomology studies, as they may present a different entomological succession. There is a need of studies using larger carcasses and repetitions to define the limit that separates the abundance between frozen and fresh carcasses.

\section{Acknowledgments}

We thank Dra. Cibele Stramare Ribeiro-Costa, MSc. Angélico Asenjo Flores and the reviewers for their helpful contributions to this paper. Also the Coordenação de Aperfeiçoamento de Pessoal de Nível Superior (KMM, RCC) and Conselho Nacional de Desenvolvimento Científico e Tecnológico (LMA) for the financial support and scholarship. This is the contribution number 1801 of the Department of Zoology, Universidade Federal do Paraná.

\section{References}

ALMEIDA, LM. and MISE, KM., 2009. Diagnosis and key of the main families and species of South American Coleoptera of forensic importance. Revista Brasileira de Entomologia, vol. 53, p. 227-244.

ARCHER, MS. and ELGAR, MA., 2003. Yearly activity patterns in southern Victoria (Australia) of seasonally active carrion insects. Forensic Science International, vol. 132, p. $173-176$.

AVILA, FW. and GOFF, ML., 1998. Arthropod succession patterns onto burnt carrion in two contrasting habitats in the Hawaiian Islands. Journal of Forensic Sciences, vol. 43, p. 581-586.

BARRETO, M., BURBANO, MA. and BARRETO, P., 2002. Flies (Calliphoridae, Muscidae) and Beetles (Silphidae) from Human Cadavers in Cali, Colombia. Memórias do Instituto Oswaldo Cruz, vol. 97, p. 137-138.

BYRD, JH. and CASTNER, JL., 2001. Forensic Entomology: The Utility of Arthropods in Legal Investigations. Florida: CRC Press.

CARVALHO, LML., THYSSEN, PJ., LINHARES, AX. and PALHARES, FAB., 2000. A checklist of arthropods associated with pig carrion and human corpses in southeastern Brazil. Memórias do Instituto Oswaldo Cruz, vol. 95, p. $135-138$.

DAY, DM. and WALLMAN, JF., 2006. A comparison of frozen/thawed and fresh food substrates in development of Calliphora augur (Diptera: Calliphoridae) larvae. International Journal of Legal Medicine, vol. 120, p. 391394.
GOFF, ML., 1991. Comparison of Insect Species Associated with Decomposing Remains Recovered Inside Dwellings and Outdoors on the Island of Oahu, Hawaii. Journal of Forensic Sciences, vol. 36, p. 748-753.

GOFF, ML., 1992. Problems in estimation of postmortem interval resulting from the wrapping of a corpse: a case study from Hawaii. Journal of Agricultural Entomology, vol. 9, p. 237-243.

GUNN, A., 2006. Essential Forensic Biology. Chichester, John Wiley and Sons, Ltd.

HAMMER, O., HARPER, DAT. and RYAN PD., 2001. PAST: Paleontological Statistics software package for education and data analysis. Paleontologia Electronica, vol. 4, p. 1-9.

INSTITUTO AGRONÔMICO DO PARANÁ. Cartas climáticas do Paraná. Available from: http://www.iapar.br/ modules/conteudo/conteudo.php?conteudo=677. Accessed in Nov. 18, 2011.

KULSHRESTHA, P. and SATPATHY, DK., 2001. Use of beetles in forensic entomology. Forensic Science International, vol. 120, p. 15-17.

MANN, RW., BASS, VM. and MEADOWS, L., 1990. Time since death and decomposition of the human body: variables and observations in case and experimental field studies. Journal of Forensic Sciences, vol. 35, p. 103-111.

MARCHENKO, MI., 2001. Medicolegal relevance of cadaver entomofauna for the determination of the time of the death. Forensic Science International, vol. 120, p. 89109.

MAZUR, S., 2002. Review of the Histeridae (Coleoptera) of México. Dugesiana, vol. 8, p. 17-66.

MICOZZI, MS., 1986. Experimental study of postmortem change under field conditions: effects of freezing, thawing, and mechanical injury. Journal of Forensic Sciences, vol. 31, p. 953-961.

MICOZZI, MS., 1997. Frozen environments and soft tissue preservation. In Haglund, WD., Sorg, MH. (Eds.). Forensic Taphonomy: The Postmortem Fate of Human Remains. Boca Raton, USA: CRC Press. p. 171-180.

MISE, KM., ALMEIDA, LM. and MOURA, MO., 2007. Levantamento da fauna de Coleoptera que habita a carcaça de Sus scrofa L., em Curitiba, Paraná. Revista Brasileira de Entomologia, vol. 51, p. 358-368.

MISE, KM., MARTINS, CBC, KÖB, EL. and ALMEIDA, LM., 2008. Longer decomposition process and the influence on Coleoptera fauna associated with carcasses. Brazilian Journal of Biology, vol. 68, p. 907-908.

MOTTER, MG., 1898. A contribution to the study of the fauna of the grave, A study of one hundred and fifity disinterments, with some additional experimental observations. Journal of New York Entomological Society, vol. 6, p. 201-231.

MOURA, MO., CARVALHO, CJB. and MONTEIRO-FILHO, ELA., 1997. A preliminary analysis of insects of medico-legal importance in Curitiba, State of Paraná. Memórias do Instituto Oswaldo Cruz, vol. 92, p. 269-274.

NAVARRETE-HEREDIA, JL., NEWTON, AF., THAYER, MK., ASHE, JS. and CHANDLER, DS., 2002. Guia ilustrada para los géneros de Staphylinidae (Coleoptera de México). Illustrated guide to the genera of Staphylinidae (Coleoptera) of Mexico. México: Universidad de Guadalajara; CONABIO.

PAYNE, JA., 1965. A summer carrion study of the baby pig Sus scrofa Linnaeus. Ecology, vol. 46, p. 591-602.

PECK, SB. and ANDERSON, RS., 1985. Taxonomy, phylogeny and biogeography of the carrion beetles of Latin 
America (Coleoptera: Silphidae). Quaestione Entomologicae, vol. 21, p. 247-317.

PUTMAN, RJ., 1978. The role of carrion-frequenting arthropodsin the decay process. Ecological Entomology, vol. 3, p. 133-139.

REGINATO, M., MATOS, FB., LINDOSO, GS., SOUZA, CMF., PREVEDELLO, JA., MORAIS, JW. and EVANGELISTA, PHL., 2008. A vegetação na Reserva Mata Viva, Curitiba, Paraná, Brasil. Acta Biológica Paranaense, vol. 37, p. 229-252.

SHALABY OA., CARVALHO, LML. and GOFF, ML., 2000. Comparison of patterns of decomposition in a hanging carcass and a carcass in contact with soil in a xerophytic habitat on the island of Oahu, Hawaii. Journal of Forensic Sciences, vol. 45, p. 1267-1273.

SMITH, KGV., 1986. A Manual of Forensic Entomology. London: Trustees of the British Museum (Natural History).

SOUZA, ASB., KIRST, FD. and KRÜGER, RF., 2008. Insects of forensic importance from Rio Grande do Sul state in southern Brazil. Revista Brasileira de Entomologia, vol. 52, p. 641-646.

STATSOFT, 2004. STATISTICA (data analysis software system), Version 7. Available from: www.statsoft.com.
STOKES, KL., FORBES, SL. and TIBBETT, M., 2009. Freezing skeletal muscle tissue does not affect its decomposition in soil: Evidence from temporal changes in tissue mass, microbial activity and soil chemistry based on excised samples. Forensic Sciences International, vol. 183, p. 6-13.

TULLIS, K. and GOFF, ML., 1987. Arthropod succession in exposed carrion in a tropical rainforest on O'ahu Island, Hawaii. Journal of Medical Entomology, vol. 24, p. 332-339.

VANLAERHOVEN, SL. and ANDERSON, GS., 1999. Insect succession on buried carrion in two biogeoclimatic zones of British Columbia. Journal of Forensic Sciences, vol. 44, p. 32-43.

VOSS, SC., FORBES, SL. and DADOUR, IR., 2008. Decomposition and insect succession on cadavers inside a vehicle environment. Forensic Science and Medical Patholology, vol. 4, p. 22-32.

ZUGIBE, FT. and COSTELLO, JT., 1993. The iceman murder: One of a series of contract murders. Journal of Forensic Sciences, vol. 38, p. 1404-1408. 